\title{
Turfs and Turfgrasses in Brazil
}

\author{
Leandro José Grava de Godoy (1)* \\ Editor - Ornamental Horticulture, Turfgrass Area, Universidade Estadual Paulista (UNESP), Registro-SP, Brazil.
}

The turf has always been and it is present in our lives. Many people have a lawn in their home, in front or at the bottom of the property, valuing the house, providing oxygen, cooling the environment, bringing more comfort to everyone. If there is no lawn in the house, going to work, there is a lawn, even if badly treated, it is there doing its job, which in addition to aesthetics, reduces dust and other particles carried by air, and helps in infiltration rainwater to replenish underground reserves. On the highway, turfgrass surrounds us, on the slopes or in the center, reduces noise pollution, caused by vehicles, and makes the view more pleasant, in addition to preventing landslides, which could be caused by rain. When you get at work, you noticed that the lawn, in front of the office, was cut and that beautiful birds look for materials for their nest or the food of the day. Upon returning to your home, you pass through the square, which has a lawn, where children play with their pets, young people exercise, while other people relax. At home, when you turn on the TV, you look at the beautiful soccer pitch, where your team will play, with even surface, without puddles of water and, without realizing it, you will be looking at, for at least 90 minutes, for a turfgrass.

For the study of turfs, it is usually divided into categories, according to the function and level of maintenance of the turfgrass. The first category is that of sod production. The turf grower is dedicated every day, for a year, irrigating, fertilizing, and maintenance, with cuts, the ideal height of the turf, controlling weeds, pests, and diseases, until the moment of the sod harvest. The sod harvest is carried out with machines, often adapted by the turf grower himself, and the sod takes a thin layer of, approximately, $0.5 \mathrm{~cm}$ of soil per harvest (per year), which represents a much smaller loss of soil than that caused by erosion. The turfgrass, for one year, are capable of sequestering from the atmosphere, on average, one ton of carbon per hectare (Qian and Follet, 2002), contributing to the environment. In Brazil, the area of sod production occupies around 25,000 hectares.

The second category includes ornamental and recreational lawns, used in homes, condominiums, parks, gardens, clubs, etc. It has the aesthetic function of ornamenting and allowing, in some cases, recreation such as playing with the dog, reading a book, having a picnic, etc. They are usually small areas, but when added together, they can represent thousands of hectares. In the USA, the area with lawns represents 16 million hectares, of which seven million are ornamental lawns (Emmons and Rossi, 2016).

The third category is sports turf, which represents the smallest area, however, the one that employs the most technology and investment. Sports turf receives the most diverse treatments to maintain "playability" as they will often be under the feet of players that cost millions of dollars. Turfgrass have a drainage system, the soil is replaced by a topsoil (sand and organic material), and system irrigation is in sectors and retractable. The turfs are planted using sods, rolls, sprigs or seeds, and then cut to a height that can vary from 30 to $3 \mathrm{~mm}$.

The fourth category is that in which the turfgrass are used to protect the soil, prevent erosion by rain and wind, reduce the formation of dust and prevent a fire from spreading on highways, airports, industrial parks, etc.

Turfs are species that cover the soil, in a more or less continuous way, and persist under periodic traffic or trampling and cutting conditions. There are different types of turfs in Brazil, which can be used in these different categories. There are 13 species and several cultivars: 1) Zoysia japonica Steud; 2) Zoysia matrella (L.) Merr.; 3) Zoysia japonica Steud. x Zoysia tenuifolia Willd. ex Thiele; 4) Axonopus affinis Chase, 5) Axonopus parodii (Valls, ined.); 6) Paspalum notatum Flüggé; 7) Paspalum notatum var. latiflorum Döll; 8) Paspaulum vaginatum Sw.; 9) Stenotaphrum secundatum (Walter) Kuntze; 10) Cynodon dactylon (L.) Pers.; 11) Cynodon dactylon x traansvaleensis; 12) Lollium perene L. and, 13) Poa trivialis L. Among these 13 species, the last two are turfs of cool-season that grow properly in colder climate conditions, but do not tolerate high temperatures. They are used in athletic fields, in the coldest regions of

\footnotetext{
*Corresponding author: leandro.godoy@unesp.br
} 
the country, during autumn-winter, to maintain the high quality and playability of these turfgrasses. The other turfs are from the warm-season, which grows very well in our tropical climate, but grows very little or even stop their growth with low temperatures.

I would like to end this editorial by paying tribute to some of the great professionals who helped to develop the turfgrass industry in our country: Agnaldo Xavier, Artur Melo, Daniel Tapia, Emerson Rocha, Ernesto Henriques, Everaldo Eller, Fábio Câmara, José Giacoia, Marcelo Matte, Maristela Kuhn, Minoru Ito, Paulo Antônio Azeredo Neto, Reinaldo Xavier, Rene Arruda, and Roberto Gurgel.

Good reading!

\section{References}

EMMONS, R.; ROSSI, F. Turfgrass science and management, $5^{\text {th }}$, Stanford CT: Cengage Learning, 2016, 608p.

QIAN, Y.; FOLLETT, R.F. Assessing Soil Carbon Sequestration in Turfgrass Systems Using Long Term Soil Testing Data. Agronomy Journal, v.94, n.4, p.930-935, 2002. DOI: 10.2134/agronj2002.9300 